\title{
Aktivitas Antibakteri Kombinasi Ekstrak Etanol Daun Johar (Cassia siamea Lamk.) dan Daun Alpukat (Persea americana Mill.) terhadap Salmonella typhi
}

\section{Antibacterial Activity Combination Of Ethanol Extract Of Johar Leaves (Cassia siamea Lamk.) And Avocado Leaves (Persea americana Mill.) Against Salmonella typhi}

\author{
Hanugrah Ardya Crisdian*, Kusumaningtyas Siwi A \\ Universitas Kusuma Husada Surakarta \\ email: hanugrahardya8@gmail.com
}

(tanggal diterima: 24 - 02- 2021, tanggal disetujui: 30 - 08 - 2021)

\section{INTISARI}

Demam tifoid merupakan penyakit demam akut yang disebabkan bakteri Salmonella typhi, 11-20 juta kasus setiap tahun dari laporan WHO 2018, 358-810/100.000 penduduk untuk negara Indonesia. Tujuan penelitian ini untuk mengetahui aktivitas antibakteri kombinasi daun johar (Cassia siamea Lamk) dan daun alpukat (Persea americana Mill) terhadap pertumbuhan bakteri salmonella typhi.

Pengujian aktivitas antibakteri kombinasi 1:1 ekstrak etanol 70\% daun johar dan daun alpukat dengan metode difusi dan dilusi, perlakuan menggunakan control (+) ciprofloxacin dan control (-) DMSO 2\% dengan seri konsentrasi 25; 50, 75 dan 100 \%. Masing-masing perlakuan dilakukan pengulangan sebanyak 3 kali.

Hasil uji aktivitas antibakteri kombinasi ekstrak etanol daun johar dan daun alpukat memiliki aktivitas terhadap bakteri Salmonella typhi paling besar pada konsentrasi 100\% dengan diameter zona bening $9.9 \mathrm{~mm}$ sedangkan terkecil rata-rata pada kosentarasi $25 \%$ diameter $6 \mathrm{~mm}$, dan siprofloksasin dengan diameter 29,3 mm. Kadar hambat minimum pada konsentrasi 12,5\%.

Kata kunci : Antibakteri; Cassia siamea Lamk; Persea Americana Mill; Salmonella typhi

\begin{abstract}
Typhoid fever is an acute febrile disease caused by Salmonella typhi bacteria, WHO 2018 data states that in the world it reaches 11-20 million cases per year, in Indonesia it reaches a prevalence rate of 358-810/100,000 population. The purpose of this study was to determine the antibacterial activity of the combination of johar leaves (Cassia siamea Lamk) and avocado leaves (Persea americana Mill) against the growth of salmonella typhi bacteria.

Testing the antibacterial activity of a combination of 1:1 70\% ethanol extract of johar leaves and avocado leaves by diffusion and dilution methods, treatment using control $(+)$ ciprofloxacin and control (-) DMSO 2\% with series concentrations of 25, 50, 75 and 100\%. Each treatment was repeated 3 times.

The results of the antibacterial activity test of the combination of ethanol extract of johar leaves and avocado leaves had the greatest activity against Salmonella typhi bacteria at a concentration of $100 \%$ with a clear zone diameter of $9.9 \mathrm{~mm}$ while the smallest average was at a concentration of $25 \%$ with a diameter of $6 \mathrm{~mm}$, and ciprofloxacin with a diameter of $29.3 \mathrm{~mm}$. The minimum inhibition level was at a concentration of $12.5 \%$.
\end{abstract}

Keywords: Antibacterial; Cassia siamea Lamk; Persea Americana Mill; Salmonella typhi 


\section{PENDAHULUAN}

Kuman patogen penyebab demam tifoid salah satunya ialah dari bakteri Salmonella typhi, infeksi sistemik dengan terjadinya demam yang berlangsung lama disertai dengan adanya inflamasi dan bakteremia yang mengakibatkan rusaknya organ hati dan usus, bakteri ini adalah penyebab utama demam tifoid. Demam tifoid merupakan infeksi yang mengancam jika tidak cepat ditangani secara baik dan bijak, bahkan dapat menyebabkan kematian. Infeksi ini mencatat 11-20 juta kasus per tahun yang mengakibatkan sekitar 128.000 -161.000 kematian setiap tahun di dunia dari laporan WHO. [1] Dari laporan surveilans tifoid dan paratifoid nasional di Indonesia sekitar 21,5 juta orang setiap tahun infeksi tifoid masih sering terjadi di negara berkembang.

Jenis tumbuhan yang mempunyai potensi untuk herbal adalah tanaman Johar (Cassia siamea Lamk). Tumbuhan ini banyak dijumpai di Asia Tenggara, termasuk Indonesia [2].Senyawa pada daun tanaman johar terdiri atas antrakuinon, saponin, ,flavonoid dan alkaloid masuk dalam metabolit sekunder [3]. Penelitian menunjukkan ekstrak air dan methanol daun tanaman johar memiliki aktivitas anti malaria, [4] anti diabetes,[5] antioksidan, [6] anti tumor dan insektisida [7] Penelitian menunjukkan ekstrak daun johar memiliki daya penghambat terhadap pertumbuhan bakteri Staphylococcus aureus, Escherichia coli, Micrococcus luteus dan Shigella dysentriae. [8]

Tanaman berikutnya yang telah banyak dilakukan penelitian pada aktivitas bakteri adalah daun alpukat berdasarkan penelitian yang dilakukan oleh Felina Alpukat merupakan tanaman yang dapat di daerah tropis dan hampir seluruhh bagian dari tanaman dapat di manfaatkan sumber pengobatan. Bagian daging buah alpukat bisa digunakan untuk melembabkan kulit kering, sariawan, menurunkan tekanan darah dan antibakteri, data hasil perhitungan rata-rata diameter zona hambat ekstrak daun alpukat dalam konsentrasi 25, 50 dan 100\% masing-masing sebesar 8,99, 10,73 dan 11,82 mm terhadap pertumbuhan bakteri Streptococcus mutan, Penelitian menyebutkan ekstrak etanol daun alpukat memiliki aktivitas antibakteri terhadap S. typhi dan S. aureus daun alpukat (Persea americana Mill) memiliki kandungan senyawa aktif berupa alkaloid, flavonoid, tannin dan golongan flavonoid yang memiliki aktivitas menghambat pertumbuhan mikroba patogen yang paling baik. [9] dari berberapa literatur menunjukan kedua tanaman ini telah diteliti dan memiki aktivitas terhadapa mikroorganisme namun belum diketahui jika dalam bentuk kombinasi, dari hal tersebut peneliti tertarik untuk mengetahui aktivitas antibakteri daun johar dan daun alpukat terhadap pertumbuhan Salmonella typhi.

\section{METODE PENELITIAN}

\section{1. ALAT DAN BAHAN}

Alat-alat yang digunakan untuk penelitian antara lain, cawan petri, tabung reaksi, Bunsen, blender, ayakan mesh 60, Erlenmeyer, rotary evaporator, corong, neraca analitik, laminar air flow, batang pengaduk, gelas kimia, autoclave, alat gelas, penyaring vakum, macam-macam pipet, jarum ose, mikroskop, jangka sorong serta penangas air. Bahan yang digunakan dalam penelitian antara lain bakteri 
Salmonella typhi, media nutrient agar [Merck], MHA (Muller Hinton Agar) [Oxoid], etanol [Ecocham], aquades steril, ciprofloxacin [Ogb Dexa], media KIA, LIA, SIM, BHI, EA, Erlich A dan B, Citrat, kristal violet, $\mathrm{NaCl}$, dan safranin.

\section{2. CARA KERJA}

Pembuatan ekstrak daun johar dan alpukat menggunakan metode maserasi dengan merendam $1 \mathrm{~kg}$ daun ditambahkan etanol 70\% 1:10 kemudian digojok sesekali 6 jam pertama diamkan 18 jam kemudian di saring dan maserasi diulang dengan jumlah pelarut setengahnya dan disaring kembali lalu dipekatkan. [10]

Golongan senyawa dilakukan identifikasi dengan menggunakan uji tabung dengan beberapa pereaksi, pengujian kandungan diantaranya senyawa saponin, flavonoid, alkaloid, dan tannin uji ini dilakukan untuk menegaskan kebenaran bahan ataupun senyawa aktif yang terkandung pada daun johar dan daun alpukat yang memiiki peran untuk aktivitas antibakteri. [11]

Pengujian antibakteri dengan metode difusi sumuran, masing-masing sumuran diisi sebanyak $50 \mu$ l ekstrak konsentrasi yaitu 100\%, 75\%, 50\%, dan 25\%, Ciprofloxsasin sebagai kontrol positif, dan DMSO 2\% sebagai kontrol negatif diinkubasi selama 24 jam pada suhu $37^{\circ} \mathrm{C}$ dan diukur diameter zona hambat sekitar sumuran yang dinyatakan dalam satuan $\mathrm{mm}$. [12]

Metode dilusi menggunakan beberapa pengenceran sebagai tahap uji antibakteri yang bertujuan untuk melihat kadar hambat minimum KHM dan kadar bunuh minimum (KBM) terhadap bakteri pengujian dilakukan sebanyak 3 kali. [12]

\section{HASIL DAN PEMBAHASAN}

Ektraksi daun johar dan alpukat dilakukan dengan maserasi dengan pelarut etanol 70\% karena etanol dapat melarutkan senyawa dari polar sampai nonpolar yang sering digunakan sehingga dapat melarutkan hampir semua senyawa kimia dalam simplisia. Rendemen ekstrak daun johar $11,2 \% \mathrm{~b} / \mathrm{b}$ dan daun alpukat 9,8\% $\mathrm{b} / \mathrm{b}$, dimana ekstrak daun johar memiliki randemen yang lebih besar dibandingkan dengan ekstrak daun alpukat, yang artinya hasil randemen menunjukkan banyaknya komponen bioaktif yang terkandung didalam ekstrak daun johar

Tabel 1. Hasil pembuatan ekstrak etanol $70 \%$ daun johar dan daun alpukat

\begin{tabular}{|c|c|c|c|}
\hline Nama Sampel & Bobot Serbuk (g) & Bobot ekstrak $(\mathrm{g})$ & Rendemen \% \\
\hline Daun Johar & $\mathbf{1 0 0 0}$ & $\mathbf{1 1 2}$ & $\mathbf{1 1 , 2}$ \\
\hline Daun Alpukat & $\mathbf{1 0 0 0}$ & $\mathbf{9 8}$ & $\mathbf{9 , 8}$ \\
\hline
\end{tabular}

Identifikasi senyawa kimia ditujukan untuk menetapkan pembuktian senyawa kimia yang terdapat pada daun johar dan daun alpukat menggunakan uji tabung dengan mereaksikan dengan beberapa pereaksi. Pengujian kandungan senyawa, flavonoid, alkaloid, saponin dan tannin. Hasil pengujian menunjukkan bahwa untuk daun johar dan daun alpukat mengandung senyawa alkaloid, flavonoid, saponin dan tannin. 
Tabel 2. Hasil Identifikasi Kandungan Senyawa Kimia Daun Johar

\begin{tabular}{|c|c|c|c|}
\hline Uji Senyawa & Hasil positif menurut teori & $\begin{array}{l}\text { Hasil Daun } \\
\text { Johar }\end{array}$ & $\begin{array}{l}\text { Hasil Daun } \\
\text { Alpukat }\end{array}$ \\
\hline \multirow[t]{3}{*}{ Alkaloid } & (pereaksi Dragendroff) warna jingga & + & + \\
\hline & (pereaksi Mayer) endapan putih & + & + \\
\hline & $\begin{array}{l}\text { (pereaksi Wagner) warna cokelat } \\
\text { kemerahan }\end{array}$ & + & + \\
\hline Flavonoid & warna jingga & + & + \\
\hline Saponin & Terbentuk busa & + & + \\
\hline Tanin & hijau kehitaman atau warna biru tua & + & + \\
\hline
\end{tabular}

Kombinasi uji antibakteri dari Ekstrak Johar Etanol (Cassia Siamea Lamk.) dapat menghambat pertumbuhan bakteri Salmonella Typhi yang ditandai dengan pembentukan area yang bening di sekitar sumuran. Area ernih dari ekstrak etanol etanol daun Johar dan alpukat terhadap bakteri Salmonella Typhi meningkat dengan konsentrasi dari 25\% hingga 100\%. Pengaruh ini terlihat dari konsentrasi yang lebih besar, semakin besar area yang bening terbentuk karena senyawa antibakteri yang terdapat dalam ekstrak etanol Johar menjadi lebih besar.

Ciprofloxacin digunakan sebagai kontrol positif. Dari data yang diperoleh bakteri Salmonella typhi sensitif terhadap ciprofloxacin, hal ini dapat dilihat dari zona bening yang terbentuk yaitu $29,3 \mathrm{~mm}$. Zona bening yang terbentuk membuktikan bahwa bakteri Salmonella typhi sensitif terhadap ciprofloxacin sesuai dengan ketentuan WHO. Bakteri Salmonella typhi dapat resisten terhadap antibiotik jika zona jernih yang terbentuk kurang dari $10 \mathrm{~mm}$, intermediet 10-13 mm dan disebut sensitif (susceptible) jika lebih dari $13 \mathrm{~mm}$ [5]. Merupakan Golongan flourquinolon generasi ke dua yang berspektrum luas, bekerja dengan menghentikan pertumbuhan bakteri maupun bakteriostatik yaitu Ciproflaksasin [6]. Sensitivitas ciprofloxacin menunjukkan lebih baik dari Kombinasi ekstrak etanol daun johar dan daun alpukat mempunyai daya dalam menghambat pertumbuhan bakteri Salmonella typhi. Namun kombinasi daun johar dan daun alpukat bisa dijadikan sebagai pengobatan tradisional digunakan tanaman herbal untuk pengobatan infeksi yang salahsatunya disebabkan oleh bekteri Salmonella typhi.

Pada penelitian ini digunakan Dimetil sulfoksida (DMSO) 2\% sebagai pengencer ekstrak etanol johar karena sifatnya yang polar dan tingkat kelarutannya tinggi sehingga ketika bereaksi dengan ekstrak etanol johar akan larut dengan sempurna. Penggunaan DMSO sebagai control negatif ditetapkan untuk menguji apakah DMSO mempunyai senyawa yang mempengaruhi data hasil penelitian. Hasil yang diperoleh dari uji kontrol negatif bahwa Dimetil sulfoksida (DMSO) 2\% tersebut tidak terdapat senyawa yang dapat berpengaruh terhadap perkembangbiakan bakteri Salmonella typhi ditunjukan dengan tidak terbentuknya zona jernih pada media petumbuhan bakteri. Hal ini sesuai dengan hasil penelitian bahwa terdapat hambatan terhadap bakteri Salmonella typhi adalah asli dari 
senyawa yang didapatkan dari hasil uji antibekteri kombinasi ekstrak etanol daun johar dan daun alpukat.

Ekstrak etanol daun johar dan daun alpukat memiliki aktivitas antibakteri dikarenakan ekstrak tersebut mengandung senyawa metabolit sekunder berupa alkaloid, flavonoid, saponin dan tannin. Hal ini didukung berdasarkan hasil uji fitokimia pada penelitian ini yang telah disajikan pada tabel 3 dan gambar 3. Cara kerja tanin sebagai antimikroba erat kaitannya pada target invasi tanin yaitu rusaknya polipeptida yang ada pada dinding sel bakteri mengakibatkan terganggunya inaktivasi sel bakteri pada sel inang [7].

Penelitian Sabir menyebutkan gugus hidroksil yang terdapat pada struktur senyawa flavonoid menyebabkan perubahan komponen organik dan perpindahan nutrisi yang akhirnya akan mengakibatkan timbulnya efek beracun terhadap bakteri. Saponin sebagai antibakteri memiliki mekanisme yaitu mendenaturasi protein dimana tegangan permukaan pada dinding sel bakteri dirurunkan dan permeabilitas membran bakteri akan dirusak sehingka terjadi kematian bekteri.

Hasil rata-rata terbesar diameter zona jernih kombinasi ekstrak etanol daun johar dan daun alpukat terhadap pertumbuhan bakteri Salmonella typhi pada konsentrasi $100 \%$ sebesar $9,9 \mathrm{~mm}$, konsentrasi $25 \%$ rata-rata terkecil diameter zona jernih $6 \mathrm{~mm}$, seri konsentrasi 75\% didapatkan rata-rata diameter zona jernih yaitu sebesar $8,1 \mathrm{~mm}$, dan konsentrasi $50 \%$ yaitu sebesar $6,7 \mathrm{~mm}$.

Tabel 3. Hasil pengukuran diameter zona bening kombinasi ekstrak daun johar dan daun alpukat terhadap bakteri Salmonella typhi

\begin{tabular}{|c|c|c|c|c|c|}
\hline \multirow[t]{2}{*}{ No } & \multirow[t]{2}{*}{ Konsentrasi } & \multicolumn{3}{|c|}{ Diameter zona hambat ( $\mathrm{mm}$ ) } & \multirow[t]{2}{*}{ Rata-rata } \\
\hline & & Replikasi 1 & Replikasi 2 & Replikasi 3 & \\
\hline 1 & $25 \%$ & 6 & 6 & 6 & 6 \\
\hline 2 & $50 \%$ & 7 & 6 & 7 & 6,7 \\
\hline 3 & $75 \%$ & 8,3 & 8 & 8 & 8,1 \\
\hline 4 & $100 \%$ & 10 & 9,8 & 10 & 9,9 \\
\hline 5 & Kontrol positif & 29,5 & 29,5 & 29 & 29,3 \\
\hline 6 & Kontrol negatif & 0 & 0 & 0 & 0 \\
\hline
\end{tabular}
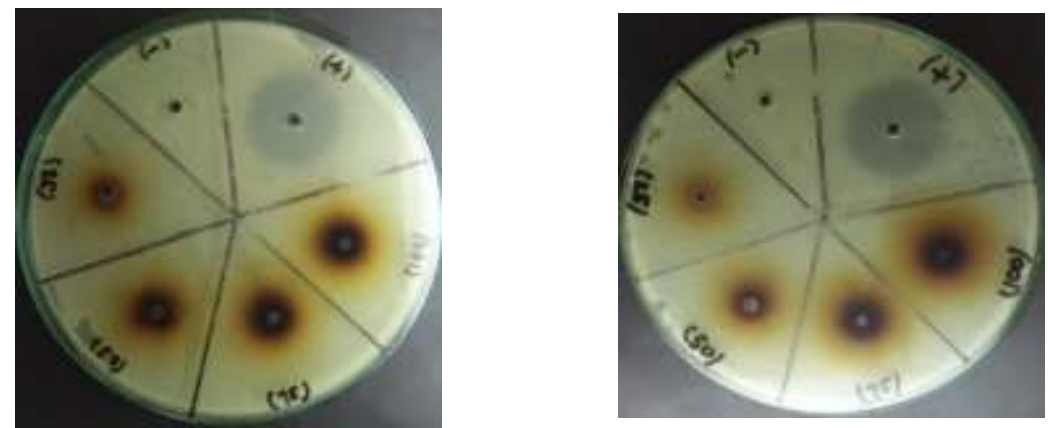

Gambar 1. Gambar Hasil Uji Difusi Kombinasi Ekstrak Daun Johar dan daun Alpukat Terhadap Bakteri Salmonella typhi 
Hasil uji untuk mengetahui nilai Konsentrasi Hambat Minimum kekeruhan tidak dapat diidentifikasi dengan adanya pertumbuhan bakteri dengan warna hijau tua gelap (Gambar 2). Kontrol positif sebagai pertumbuhan bakteri yang berisikan koloni bakteri, ekstrak daun johar sebagai kontrol negatif tidak terlihat pertumbuhan bakteri.

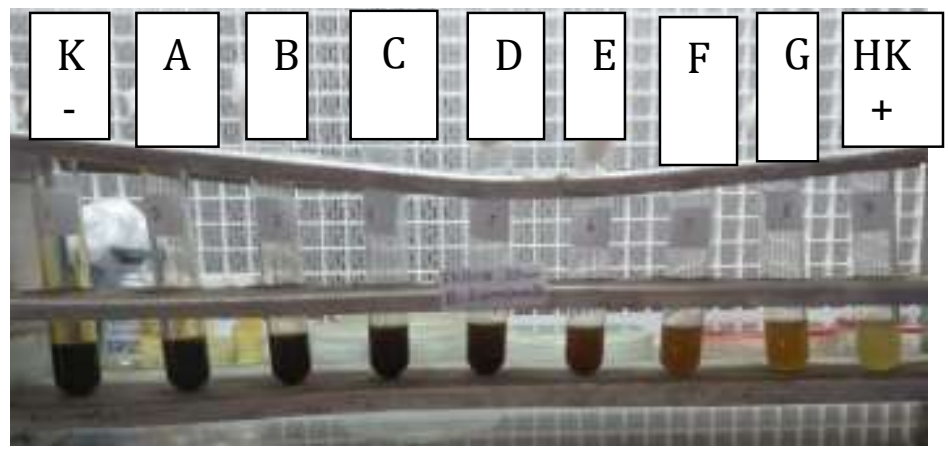

\section{Gambar 2. Gambar Hasil Uji Aktivitas Antibakteri Ekstrak daun Johar terhadap bakteri Salmonella Thyphi menggunkan cara dilusi}

\section{Keterangan:}

A = Kombinasi ekstrak daun Johar dan alpukat $50 \%+$ bakteri Salmonella typhi

B = Kombinasi ekstrak daun Johar dan alpukat $25 \%+$ bakteri Salmonella typhi

C = Kombinasi ekstrak daun Johar dan alpukat $12,5 \%+$ bakteri Salmonella typhi

D = Kombinasi ekstrak daun Johar dan alpukat 6,25\% + bakteri Salmonella typhi

$\mathrm{E}=$ Kombinasi ekstrak daun Johar dan alpukat 3,125\% + bakteri Salmonella typhi

$\mathrm{F}=$ Kombinasi ekstrak daun Johar dan alpukat 1,562\% + bakteri Salmonella typhi

$\mathrm{G}=$ Kombinasi ekstrak daun Johar dan alpukat $0,781 \%+$ bakteri Salmonella typhi

$\mathrm{K}+=$ Suspensi bakteri

$\mathrm{K}-=$ Kombinasi ekstrak daun Johar dan alpukat johar 50\%

Tabel 4. Hasil Uji Penentuan Nilai Kadar Bunuh Minimum

\begin{tabular}{|c|c|c|c|}
\hline Konsentrasi $(\%)$ & Replikasi 2 & Replikasi 3 \\
\hline $50 \%$ & - & - & - \\
\hline $25 \%$ & - & - & - \\
\hline $12,5 \%$ & - & - & - \\
\hline $6,25 \%$ & + & + & + \\
\hline $3,125 \%$ & + & + & + \\
\hline $1,562 \%$ & + & + & + \\
\hline $0,781 \%$, & + & + & + \\
\hline K+ & + & + & - \\
\hline K- & - & - & + \\
\hline
\end{tabular}

Penentuan Konsentrasi Bunuh Minimum dilakukan dengan cara dilusi cair dengan media MHA (Mueler Hinton Agar) dimana bakteri digores pada campuran ke masing-masing tabung reaksi. 


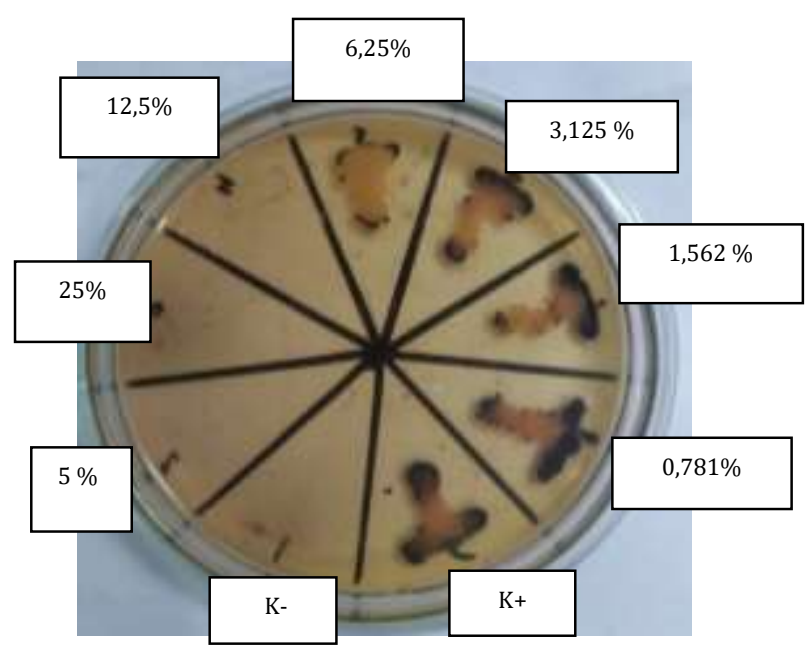

Gambar 3. Gambar Hasil Uji Penentuan KBM dengan Penggoresan pada Media MHA

Hasil pertumbuhan bakteri positif ditunjukkan dengan adanya pertumbuhan bakteri di media MHA. Hasil penggoresan dapat dilihat di tabel 4 dan gambar 3. Data yang diperoleh dari hasil penggoresan bakteri dengan metode dilusi cair pada media MHA setiap konsentrasi hasil uji aktivitas antibakteri ditunjukkan pada replikasi 1,2 dan 3 nilai Konsentrasi Bunuh Minimum (KBM) kombinasi ekstrak daun johar terhadap bakteri Salmonella typhi sebesar 12,5\%. Hal ini ditunjukkan dengan tidak tumbuhnya bakteri pada kosentrasi tersebut.

\section{KESIMPULAN}

Aktivitas antibakteri terhadap bakteri Salmonella typhi terdapat pada kombinasi ekstrak etanol daun johar (Cassia siamea Lamk) dan daun alpukat (Persea americana Mill.), Konsentrasi kombinasi ekstrak etanol daun johar (Cassia siamea Lamk.) dan daun alpukat (Persea americana Mill.) yang memiliki aktivitas paling besar adalah $100 \%$ diikuti dengan $75 \%$ dengan diameter zona hambat ratarata $9.9 \mathrm{~mm}$ dan $8,1 \mathrm{~mm}$, Kosentrasi hambat minimum kombinasi ekstrak etanol daun johar (Cassia siamea Lamk.) Dan daun alpukat (Persea americana Mill.) tidak dapat dilaporkan karena tidak bisa terlihat sedangkan kadar bunuh minimumnya pada konsentrasi $12,5 \%$.

\section{UCAPAN TERIMAKASIH}

Kepada Universitas Kusuma Husada Surakarta yang memberikan dukungan dalam proses penelitian

\section{DAFTAR PUSTAKA}

[1]. WHO. 2018. Drug Resistance: Antimicrobial use. World Health Organization Program and Projects. http://www.who.int/drugresistance/use/en/ (diakses 3 Maret 2020).

[2]. Kemenkes . 2011. Modul Penggunaan Obat Rasional. Jakarta : Direktorat Jendral Bina Kefarmasian dan Alat Kesehatan 
[3]. Hutapea, J.R, dkk. 1994. Inventaris Tanaman Obat I. Jakarta: Depkes. RI Badan Penelitian dan Perkembangan Kesehatan.

[4]. Ajaieoba, E.0, J.S. Ashidi, L.C, P.J. Houghton and C.W.Wright. 2008. Antiplasmodial Compounds from Cassia siamea Stem Bark Extract. Phytotherapy Research 22 (2): 252-254

[5]. Kumar dan O. Prakash. 2010. Antidiabetic and Aanti-lipemic Effects of Cassia siamea Leaves Extract in Streptozotocin Induces Diabetic rats. Asian Pasific Journal of Tropical Medicine, 871 - 873.

[6]. Kaur, G., M.S. Alam, Z. Jabbar, K. Javed dan M. Athar. 2006. Evaluation of Antioxidant Activity of Cassia siamea flowers. Journal of Ethnopharmacology 108 (3): $340-348$.

[7]. Kardono, L. B. S., et al. 2003. Selected Indonesian Medical Plants : Monographs and Descriptions Volume 1. Jakarta: PT Gramedia Widiasarana Indonesia.

[8]. Fitri, Mapiratu, dan Prismawirayanti. 2017. Uji Aktivitas Antibakteri Ekstrak Daun Tanaman Johar (Cassia Siamea Lamk.) dari Beberapa Tingkat Kepolaran Pelarut. KOVALEN, 3(3):242-252.

[9]. Azzahra, F., E. A. Almalik., A. A. Sari. 2019. Uji Aktivitas Antibakteri Dari Ekstrak Etanol Daun Alpukat (Persea Americana Mill.) Terhadap Bakteri Salmonella typhi dan Staphylococcus aureus. Jurnal Kefarmasian Akfarindo. 4 (2): 5-6

[10]. Kemenkes RI. 2017. Edisi II Farmakope Herbal Indonesia. Jakarta: Direktorat Jenderal Bina Kefarmasian dan Alat Kesehatan. Hlm 531.

[11]. Setyo WA, Sri RDA, Ashadi, Bakti Mulyani, Cici PR. 2014. Skrining Fitokimia Dan Identifikasi Komponen Utama Ekstrak Metanol Kulit Kayu Durian (Durio zibethinus Murr.) Varietas Petruk. Seminar Nasional Pendidikan dan Kimia VI. ISBN: 9779373184-0 : 271-279.

[12]. D., Idiawati, N. and Sitorus, B., 2015. Uji Aktivitas Antibakteri Dari Ekstrak Daun Malek (Litsea graciae Vidal) Terhadap Bakteri Stapylococcus aureus dan Escherichia coli. Jurnal Kimia Khatulistiwa, 4(1), pp.8-12. 